\title{
FRAME ANALYSIS OF POLITICAL TEXTS
}

\author{
Nataliia Dyachuk \\ n-dyachuk@mail.ru \\ Ivan Franko Zhytomyr State University, Ukraine
}

\author{
Received May 8, 2017; Revised May 15, 2017; Accepted May 27, 2017
}

\begin{abstract}
The article outlines the study of political texts from psycholinguistic perspectives. The research generalizes and empirically verifies a psycholinguistic approach to the study of political discourse and focuses on frame analys is, one of the most powerful psycholinguistic techniques. Frame structure embraces conceptual components that allow accumulating information from different sources. The public speeches of two great Ukrainian and American political leaders Viktor Yushchenko and Barack Obama were the principal sources of the analysis. Frame analysis was applied to study cross-cultural peculiarities that depict national nature of two cultures. Data analysis shows that discourse of the Ukrainian leader is mostly focused on categories such as people, power, liberty. The discourse of the American leader contains categories such as economy, money, people, psychological constructs. The results show that people have become top-priority for V. Yushchenko. They are the people the Ukrainian politician addresses, believes and trusts. V. Yushchenko also focuses on freedom, independence and liberty of any Ukrainian citizen. B. Obama is deeply concentrated on economy and finance of his country. It has become obvious that he is ready to imple ment the set of reforms for the country to thrive. The category of psychological constructs shows that the American politician is full of respect and proud for his country ant population. The radical variety of two speeches is caused by different economic conditions, values and mentality of two cultures and personal purposes and objectives of the two politicians.
\end{abstract}

Keywords: frame analysis, political texts, frames (slots), political leaders, categories, prototype representatives, cross-cultural peculiarities.

Дячук Наталія. Фреймовий аналіз політичних текстів.

Анотація. Стаття висвітлює погляд на полігичні тексти 3 позицій психолінгвістики. У статті обгрунтовано та емпірично підтверджено психолінгвістичний підхід до вивчення політичного дискурсу. Стаття посилається на фреймовий аналіз, один із потужніших методів психолінгвістичного дослідження. Для проведення фреймового аналізу було обрано політичні промови двох великих полігичних лідерів України та Америки Віктора Ющенка та Барака Обами. Фреймовий аналіз було застосовано для вивчення міжкультурних особливостей, які зображають національний характер двох культур. Результати аналізу свідчать, що дискурс українського лідера вміщує такі найбільш значущі категорії, як люди, влада, свобода. Дискурс Американського лідера включає такі суттєві категорії як: економіка, гроші, люди, психологічні конструкти. Результати дослідження засвідчили, що пріоритетним для В. Ющенка є люди, до яких він звертається, яким він вірить, на яких покладається. Серед пріоритетів українського лідера знаходяться свобода та незалежність кожного українця. Барак Обама більш зосереджений на проблемах економічного та фінансового положень країни. Очевидним виявилося, що майбутній президент готовий запровадити ряд реформ для процвітання своєї держави. Лексичне наповнення категорії психологічні конструкти засвідчило, що американський лідер виявляє повагу та гордість до свого народу. Радикальні зміни свідчать про

(C) Dyachuk, Nataliia (2017). East European Journal of Psycholinguistics, 4(1), 40-46. DOI: 10.5281/zenodo.824511 
різну економічну ситуацію в країнах, різну менталітет та цінності представників двох культур, а також різні цілі та установки кожного з мовців.

Ключові слова: фреймовий аналіз, політичні тексти, фрейми (слоти), політичні лідери, категорії, прототипні представники, мізкультурні особливості.

\section{Introduction}

Frame analysis is considered to be one of the most powerful techniques for investigating a political thought. The term "frame" was introduced by M. Minsky at the beginning of the 1970s. The scholar defined frame as a term for datastructure representing stereotyped situation (Minsky, 1975). The situation can designate an action, image, a story, etc. Frame structure embraces conceptual components accumulate information, the content of which is reflected in the title slot. Frame is a set of standard real or potential knowledge devoted to the complex phenomena, entire idea of complex concept. Frame is viewed as an open-end system that can enrich its data channel by the stream of new information (Sternin, 2001).

Frame analysis theory has been considered one of the most promising and challenging studies in the last decades. This is primarily explained by its interdisciplinary nature, as having integrated into various linguistic and non-linguistic knowledge domains, frame analysis makes it possible to explain a plenty of language phenomena from the point of view of cognitive analysis. Frame is defined as a universal category that is able to combine different kinds of human knowledge, their experience and is widely characterized by its maximum formality and polyhistory. The accent is put on the absence of clear boundaries between linguistic meanings and human experience - transition continuity from language to experience. It must be assumed that absolute frame identification with various associations would be misleading. Frames are not simple associations that can recur to an individual's memory: any frame is endued with core, generic and possible information that is structured in certain units used to demonstrate the knowledge (Nikonova, 2006).

Frame study has become a key foundation for different types of mental units (built upon perception or imagination) and their verbalization. Frame is a knowledge structure created to connect mental space with verbal. With the help of frame mental structure could be transformed into verbal.

Thus a considerable amount of research has been carried out in the last few decades aiming to explain the concept "frame" (Z. Burdina, K. Baker, L. NizhehorodtsevaKyrychenko, Zh. Nikonova, U. Karpenko, S. Kozak, Z. Popova, I. Sternin, A. Babushkin, Ch. Fillmore, D. Tannen, T. A. van Dijk, W. Dressler and others). The soviet and foreign scientists are increasingly attempting to view the concept "frame" as an effective means to analyze the knowledge in any language system. Language is seen to be the highest peak of a cognitive iceberg. It leads to the occurrence of various models and frames in a person's mind. Therefore, frame analysis points toward recognizing a frame or a set of frames that populate a particular sphere of concepts 
(Alimuradov, 2009). Frame is often considered to be a unique organization of a representing cognitive apparatus of human knowledge while unifying cognitive and linguistic fields in the process of speaking (Nikonova, 2008).

It is fundamental to mention that unlike other cognitive units (concept or image) frame is supposed to be a meaningful basis of a pre-planning utterance. The main objective of the concept study which covers the most common and significant frame features is the selection of frame prototype, which is the top of the frame. A prototype reflects the national nature of different countries and cultures.

Any political regime can't but exist without communication. Language is viewed as a means to persuade, inform, order etc. The specific characteristic of politics unlike other areas of human activity lies in its discursive nature. Thus most political actions are said to be speech actions within this format (Sheygal, 2004). Therefore political activity is often regarded to be speech activity as well.

\section{Methods}

The main sources of our investigation are the public speeches of two great Ukrainian and American political leaders Viktor Yushchenko (Yushchenko, 2004) and Barack Obama (Obama, 2007). Frame analysis was applied in order to study cross cultural peculiarities that depict national nature of two cultures.

To organize the empirical research the political speeches of two politicians have been chosen. The procedure embraced some stages. On the first stage all the lexical units expressed by nouns have been noted. On the second stage all matching words have been grouped into the categories. On the third stage the amount of lexical contents of each category has been analyzed. On the fourth stage the coefficient of prototype representative frequency and proportion of each category have been estimated. Finally, the concepts that reflect events according to the scheme Pre-Event-Event-Post-Event among keywords have been chosen. These concepts shape the script of the analyzed texts (Zasiekina \& Zasiekin, 2008).

\section{The study}

To organize the empirical research all the matching words of both political speeches were grouped into specific categories.

Data analysis shows that discourse of the Ukrainian leader is mostly focused on categories such as people, power, liberty. The discourse of the American leader contains categories such as economy, money, people, and psychological constructs.

However discourse category gradation radically differs. The categories in the Ukrainian leader's speech are far bigger in volume, thus they contain more frames to show the content of this or that category. Obama's speech doesn't include categories such as power, liberty, strength, bodyparts (see: figures 1,2) 


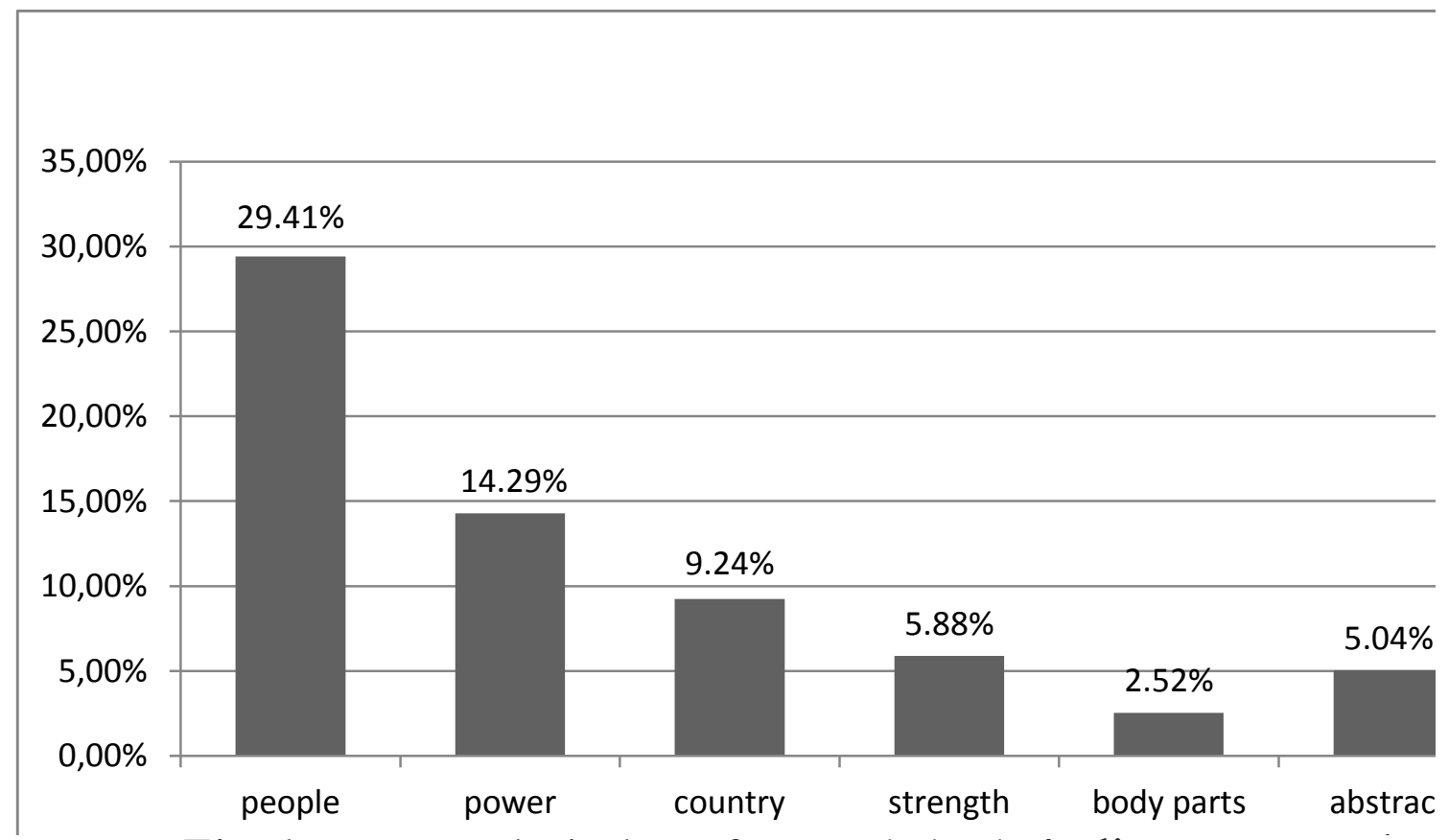

Fig. 1. Frame analysis data of V. Yushchenko's discourse

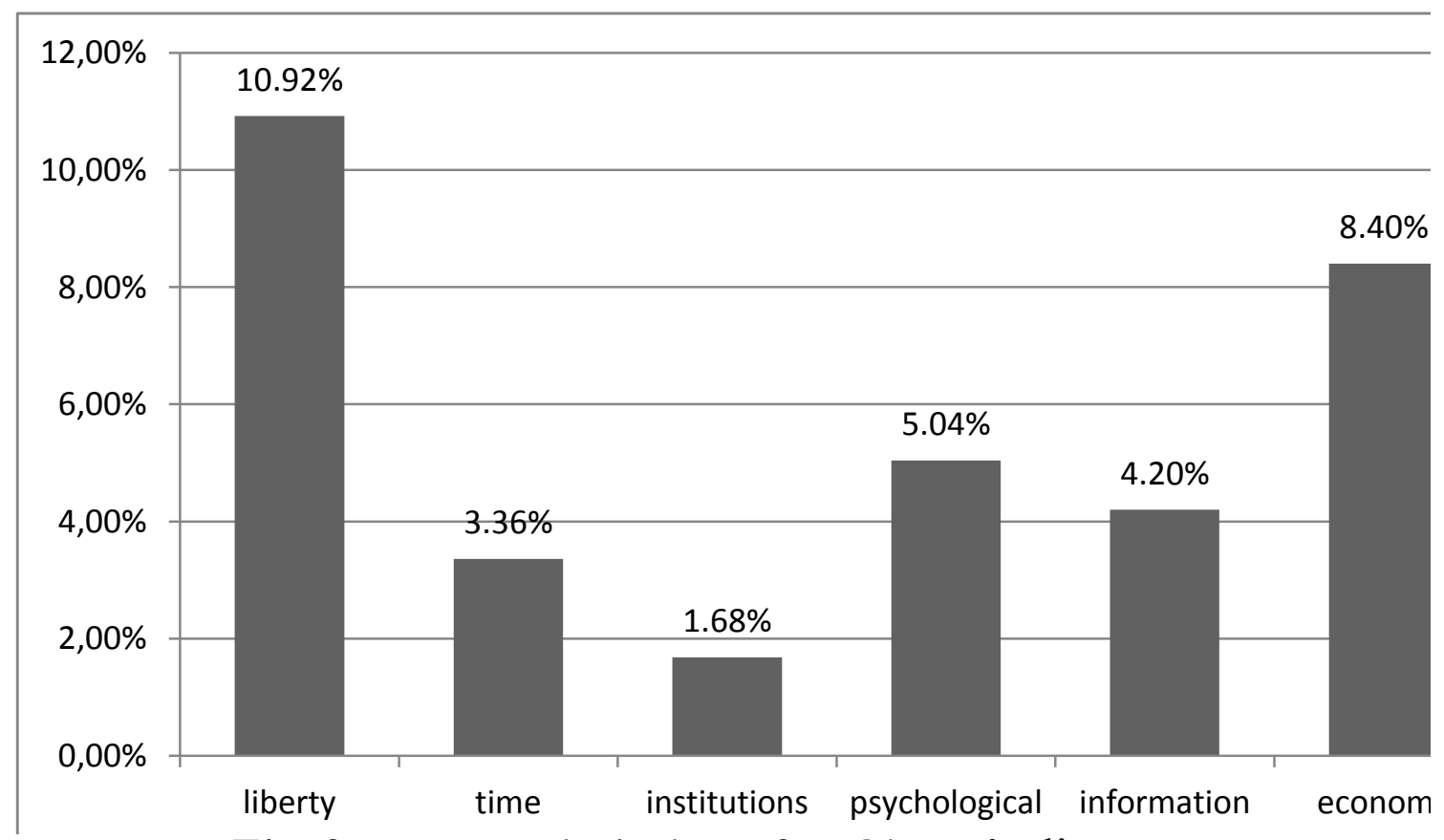

Fig. 2. Frame analysis data of B. Obama's discourse

Data analysis shows that the most accurately filled categories (slots) in V. Yushchenko's speech contain the following prototype representatives:

lyudy (people): Hospod' Boh (The Lord God) - 0.03; lyudy (people) - 0.17; vybortsi (electorate) - 0.14; likari (doctors) - 0.03; druzhyna (wife) - 0.03; dity (children) - 0.03; rodyna (family) - 0.03; mil'yony (millions) - 0.23; ukrayintsi (Ukrainians) - 0.11; maidan (public square) - 0.11; susid (neighbour) - 0.03; druzi (friends) - 0.09; khrystyyany (Christians) - 0.03; ahrariyi (farmers) - 0.03; 
skhidnyak (easterner) - 0.03; zakhidnyk (westerner) - 0.03; hromadyany (citizens) 0.03; spadkoyemnist' (succession) - 0.03;

vlada (power): zakon (law) - 0.11; vlada (power) - 0.41; uryad (goverment) 0.06; livi (the Left) - 0.06; pravi (the Right) - 0.06; demokraty (Democrats) - 0.06; Ukrayina (Ukraine) - 0.2;

volya (liberty): stabil'nist' (stability) - 0.15; vybir (choice) - 0.15; slava (glory) - 0.23; dolya (fate) - 0.15; perspektyvy (perspectives) - 0.08; rozvytok (development) - 0.08; zberezhennya (preservation) - 0.08 .

The text of the American leader contains frames such as economy and money. people. psychological constructs.

The first group of categories embraces such slots as economy (0.12), recession (0.048), concern (0.02), opportunity (0.02), crisis (0.048), job (0.02), business $(0.02)$, weight $(0.02)$, decline $(0.02)$, problem $(0.02)$, reach $(0.02)$, entrepreneurs (0.02), measure (0.02), market (0.07), source (0.048), cost (0.02), saving (0.02), money (0.02), debt (0.02), gains (0.02), payment (0.02), surplus (0.02), wealth (0.02), profit (0.02), debates (0.02), loan (0.02), expense (0.02), oil (0.02), force (0.02), prosperity (0.048), reform (0.02), regulation (0.02).

The category people contains such frames as men (0.12), Americans (0.12), women (0.12), friend (0.06), neighbor (0.06), member (0.06), family (0.06), child (0.12), people (0.12), nation (0.06), government (0.12).

The category psychological constructs consists of such notions as dream $(0,07)$. worry (0.07), impact (0.07), confidence (0.07), destiny (0.07), state (0.07), imagination (0.07), pride (0.07), responsibility (0.21), care (0.07), survival (0.07), decision (0.07).

\section{Discussion}

The category people is the most sizeable in the speech of the Ukrainian leader. Hence people seemed to be of primary importance for V. Yushchenko. The leader refers to his population as he looks for a hope and trust. He expects to have something beneficial from the Ukrainians in the future. Thus he calls for Ukrainians' reliance, integrity, strength, ability and confidence.

The category is characterized by the powerful content as the politician focuses on professional differences (doctors and farmers) and the territory for living (easterner and westerner). The orator lays the stress on equality of Ukrainians (doctors and farmers are of equal rank for him), not differentiating between mental work and manual labour or cardinal directions.

The profound emphasis is put on the struggle for Ukrainians' freedom, liberty and independence. The significant accent is also put on the fight against corruption.

The absence of the category economy shows that the economic prospects of the country has not been outlined and a clear plan to change the economic situation in Ukraine has not been indicated. Hence, the president-to-be of Ukraine mostly focuses on the preserving of the territorial integrity, its independence relying on strong support of his electorate. 
By contrast, B. Obama pays much attention to country's economy and finance. The prototype representatives used by B. Obama show that with his hold ing the post of the president he promises to introduce a series of reforms for resolving economic issues. Moreover, he hopes to implement critical issues realization by addressing each individual and the nation as the whole. He calls for every American to cooperate, work in coordination and in an organized way, affecting their psychological characteristics: worship, trust, devotion etc. The category containing frames of psychological constructs has become of great importance as it abounds with the slots that make it possible to be proud of the country, be sure about country's thriving and success. The great accent is put on speech acts that have been used to express a serious support and trust to his people.

Hence, the politics of two great leaders bears different marks. The values that have become important for one leader is somewhat modified and various for another one. This fact is determined by a diverse economic situation in countries, different speakers' mentality and personal values, various goals, aspirations and desires they set.

\section{Conclusions}

As the political discourse is becoming increasingly popular nowadays scholars attempt to pay more attention to various research methods to study its realia. Frame analys is makes it possible to model the basic politician's guidelines, preferences, interests, future political plans, ideas about his friends and enemies, state, society as a whole, predict the leader's behavior in further circumstances. This approach will help to recognize the true motivation of a politician's coming to power, clearly view the results of his future actions and shape a highly-developed society with the support of the leader who truly seeks to positively influence the life of the country, using the successful experience of other politicians and their predecessors.

\section{References}

1. Алимурадов О. Картины языка музыки. Функционально-семантическая характеристика современной английской музыкальной лексики: когнитивнофреймовый подход. М.: КРАСАНД, 2009.

Alimuradov, O. (2009). Kartiny Yazyka Muzyki. Funktsional'no-Semanticheskaya Kharakteristika Sovremennoy Angliyskoy Muzykal'noy Leksiki: Kognitivno-Freymovyy Podkhod [Pictures of the Language of Music. Functional-Semantic Characteristics of Modern English Musical Vocabulary: Cognitive-Frame Approach]. Moscow: KRASAND.

2. Minsky, M. (1975). A framework for representing knowledge. In: The Psychology of Computer Vision (pp. 211-277), P.H. Winston (ed.). New York: McGraw-Hill.

3. Никонова Ж. Теория фреймов в лингвистических исследованиях. СПб: СпбГУ, 2006. Nikonova, Zh. (2006). Teoriya Freymov v Lingvisticheskikh Issledovaniyakh [The Theory of Frames in Linguistic Studies]. S.-Petersburg: S.-Petersburg State University.

4. Никонова Ж. Основные этапы фреймового анализа речевых актов // Вестник Нижегородского университта им. Н. И. Лобачевского. 2008. № 6. С. 224-228.

Nikonova, Zh. (2008). Osnovnyye etapy freymovogo analiza rechevykh aktov (na materiale sovremennogo nemetskogo yazyka) [The main stages of frame analysis of 
speech acts (on the basis of modern German language]. Vestnik Nizhegorodskogo Universiteta im. N. I. Lobachevskogo, 6, 224-228

5. Шейгал Е. Семиотика политического дискурса. М.: Гнозис, 2004.

Sheygal, Ye. (2004). Semiotika Politicheskogo Diskursa [The Semiotics of Political Discourse]. Moscow: Gnozis.

6. Стернин И. Методика исследования структуры концепта. Воронеж, 2001.

Sternin, I. (2001). Metodika Issledovaniya Struktury Kontsepta [Methodology for Studying the Structure of the Concept]. Voronezh: Voronezh University.

7. Засєкіна Л., Засєкін С. Психолінгв істична діагностика. Луцьк: Вежа, 2008.

Zasiekina, L, Zasiekin, S (2008). Psyholinhvictychna Diahnostyka [Psycholinguistic Diagnostics]. Lutsk: Vezha.

\section{Sources}

1. Obama, B. (2007) Barack Obama's campaign speech. Retrieved from http://www.theguardian.com/world/2007/feb/10/barackobama.

2. Ющенко В. Слухай своє серце, керуйся своїм розумом!// Високий замок. № 185(3).

Yushchenko, V. (2004) Slukhay s voye sertse, keruysya svoyim rozumom! [Listen to your heart; be guided by your mind!]. Vysokyy Zamok, 185, 3. 